\title{
The Dynamic Impact Of The Demand And Supply Constraints On U.S. Trade With African Countries: A Case Study Of Selected Countries
}

Nkanta Frank Ekanem, (E-mail: fekanem@howard.edu), Howard University

\begin{abstract}
Although we conclude that the countries in the sample have a high marginal propensity to import, generally significantly greater than unity, and a very low marginal propensity to export, we can never claim to know why there has been so little trade between the United States and Africa. For that reason we must avoid making any general conclusion, even for countries with identical economic conditions.
\end{abstract}

\section{INTRODUCTION}

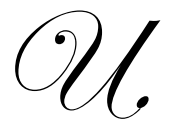

S. trade with the African continent has been very insignificant prior to the 1990's. This limited trade between the U. S. and African countries is generally believed to be due to "the lack of U. S. awareness of Africa as a market for traded goods and services rather than merely a source of raw materials". In the 1970 's and most of 1980's, the U. S. exports and imports as a ratio of the respective African countries' GDP were significantly less than $5 \%$ in many instances. During the latter part of the 1980 's, when the United State's awareness of Africa as a potential trading partner was believed to have increased, following economic reforms emphasizing growth, openness and private sector development, the ratio of the U. S. exports and imports to some countries continued to remain very low. According to (Rogers, 1998), these economic reforms had led to an increase in the number of African countries qualifying as potential candidates for trade, (Rogers 1998), but sadly enough, not to the extent that can stimulate significant increase in trade. However, since 1980 's, total U. S. exports to Africa increased by $69 \%$, from $\$ 6,283$ in 1987 to $\$ 10,615$ in 1996 . U. S. imports from Africa also increased by 57\% from $\$ 11,939$ in 1987 to $\$ 18,744$ in 1996 .

In spite of these trends, a comparison of the U. S. trade with selected non-African countries, where the U. S. has been more inclined to promote meaningful trading relationship clearly reveals the paucity of American trade with the African continent. During this period, U. S. exports to Mexico increased by $259.5 \%$ from $\$ 14,582$ in 1987 to $\$ 56,792$ in 1996 . Imports increased by $266.5 \%$ from $\$ 20,271$ to $\$ 74,297$. U. S. exports to Japan increased by $139.5 \%$ from $\$ 28,249$ and imports from Japan increased by $36.2 \%$ from $\$ 84,575$ to $\$ 115,187$ during the same period (U. S. Department of Commerce). This paper is an attempt to critically examine the root causes of this limited trade between the United States and Africa. We use data from a sample of six African countries from 1970-2002, to test the hypothesis that the pervasive demand-side and supply-side constraints do not allow African countries to significantly increase their exports to U. S. A. at any given time, even when there is significant increase in the demand for such exports in the U. S. market. Similar the demand constraints in Africa also prevent the U. S. exporters from significantly increasing their exports to Africa, even if the U. S. exporters are eager to do so. 


\section{THE THEORY}

The model used in this study is an inverse function of the (Tyler, 1981), and similar models, which explain the GDP growth as a function of the growth rate of exports, capital formation, and the labor force. These models assume that a country can increase its exports, given its stock of capital, labor and various environmental factors such as labor productivity, efficiency of capital and shifts from domestic to the export sector, (Tyler,1981), (Feder, 1982), and (Esfahani, 1991). Two models are considered in this study. Model one deals with the U. S. exports to Africa, and model two deals with African exports to the U. S. Each of these models faces its unique constraint. The model, which explains the U. S. exports to Africa faces demand constraint in the form of limited purchasing power in Africa. We use African country's per capita GDP and the country's GDP, relative to U. S. GDP to explain the variability in the country's imports due to the demand constraints. Model two; on the other hand faces supply-side constraints. The constraints are in the form of the African country's inability to offer a significant amount of export products when the demand for them in the U. S significantly increases. There are two reasons for this. The most important reason for this is that most African countries lack the capacity to expand their production in the short run. The second reason is that their exports are not competitive in price and quality, and hence face considerable competition from other potential exporters to the U. S. market. African country's GDP, relative to U. S. GDP and the industrial production index (IPI) are used to explain the variances in their exports due to these supply-side constraints.

Per capita GDP is considered to be an important supply-side constraint in two respects, firstly the size of the GDP determines the amount of the resources available to generate exports. High per capita GDP reflects the country's ability to produce for domestic and export markets, and vice versa. Secondly the GDP is an embodiment of the level of development which determines the level and quality of technology and social infrastructure, such as communications, transportation and energy, and hence the degree of efficiency in the production of goods and services. These factors are important in the determination of relative export prices. Where data is available, industrial production index (IPI) is also included in the model, which explains the African exports to the United States. IPI directly affects the output and price of manufactured, and indirectly the price of primary export products. Although African countries do not possess any degree of comparative advantage in manufacturing, the industrial production index is included in this model as a constraint variable that limit the countries' ability to export. It is assumed that a low industrial production index reduces the country's ability to export, whereas a high industrial production index enhances its ability to export. Where data on industrial production is unavailable, as in the case of Egypt and Ethiopia, we rely on the country's per capita GDP as its main supply-side constraint at the risk of misspecification error. The last environmental factor included in both models is real exchange rate. International trade theory asserts that overvalued currency renders exports relatively expensive because more of the importing country's currency is required to purchase its imports. For this reason, overvalued currency tends to limit the ability of any country to export. On the other hand overvalued currency renders imports relatively cheaper and so induces more imports by the country with the overvalued currency.

The estimated models are:

$\log \left(\mathrm{E}_{\mathrm{ua}}\right)=\log \alpha_{0}+\alpha_{1} \log \left(\mathrm{Y}_{\mathrm{a}} / \mathrm{Y}_{\mathrm{u}}\right)+\alpha_{2} \log \left(\mathrm{Y}_{\mathrm{a}} / \mathrm{L}_{\mathrm{a}}\right)+\alpha_{3} \log ($ rer $)+\mu$

$\log \left(\mathrm{E}_{\mathrm{au}}\right)=\log \beta_{0}+\beta_{1} \log \left(\mathrm{Y}_{\mathrm{a}} / \mathrm{L}_{\mathrm{a}}\right)+\beta_{2} \log (\mathrm{IPI})+\beta_{3} \log ($ rer $)+v$

$\mathrm{E}_{\mathrm{ua}}$ represents US exports to Africa and $\mathrm{E}_{\mathrm{au}}$ represents African exports to USA, Y represents nominal GDP, L represents population (labor), rer represents real exchange rate, and IPI represents industrial production index.

Model one assumes that with its enormous resources and potentials to export, the United States can export as much as it wishes to Africa. However, many African countries with low per capita GDP lack the capacity to purchase US imports. For this reason, US exports to Africa face serious demand constraints. 
The models assume as follows:

$0<\alpha_{1}, \alpha_{2}<1$

$0<\beta_{1}, \beta_{2}<1$

$0<\alpha_{3}, \beta_{3}<1$

Due to the assumed demand-side and supply-side constraints, both the marginal propensities to import and export are assumed to be inelastic. Although this is often determined by administrative actions rather than market forces, we consider real exchange rate as another important supply-side constraint. A case in point is the usual parallel exchange rate regime, which allows one rate to be reserved for the importation of critical commodities, such as raw materials, energy and capital equipment needed for the execution of government sponsored development programs, and the other reserved for other commercial activities. We assume in this case that exchange rate policies are determined by market forces for all non-petroleum commercial transaction, and not by cartel-type production guidelines.

The model assumes that neither exports nor imports are expected to respond significantly to take advantage of real exchange rate appreciation or depreciation. Where currencies are not grossly overvalued, the United States can still increase its export in the short run, if the exchange rate effect dominates the income effect, and vice versa, in spite of the low per capita income and demand constraints, especially if such products are critical inputs for domestic industries or government sponsored development projects. Given a proper alignment of its currency, model two assumes that African exports to the U. S. market depend only on the African country's ability to generate the exports. This ability is measured by the country's per capita GDP, labor productivity or both. The supply flexibility is assumed to be greatly impaired by poor quality of infrastructure, technology, and low productivity. For these reasons exports can hardly be increased in the short run to take advantage of demand increases.

\section{THE SAMPLE AND DATA DESCRIPTION}

The sample for this study is drawn from countries with significant trade with USA for which a complete set of data on imports, exports, consumer price index (CPI), exchange rate, and other variables are available for the period 1970-2002. Many of the countries did not have annual data on imports and exports. In some cases data were missing for up to five or even seven years. For this reason extrapolation had to be used to generate the missing observations. Import and exports in some of the countries in our sample have growth trends that extend to over five years in certain cases. For these reasons, it was considered necessary to test for the characteristics of the data, to determine the appropriate specification procedure for the vector auto-regressions. Due to the growth trend observed in some of the variables used, it was determined that error correction with deterministic model was an appropriate estimation method

\section{UNIT ROOT TEST}

As indicated above, many of the variables possessed growth trends therefore it was considered necessary to determine whether the variables are difference stationary or trend stationary. A series is said to be stationary if the means and autocovariances of the series do not depend on time. This calls for testing the null hypothesis that the variables contain a unit root so that it is non-stationary, and therefore follows a random walk process. Two unit root tests were performed, namely the Augmented Dickey-Fuller (ADF) and Philips-Perron (PP) tests:

$$
\begin{aligned}
& \text { ADF test: } \Delta \mathrm{y}_{\mathrm{t}}=\mu_{0}+\gamma_{1} \mathrm{y}_{\mathrm{t}-1}+\Sigma \delta_{\mathrm{k}} \Delta \mathrm{y}_{\mathrm{t}-\mathrm{k}}+\varepsilon_{\mathrm{t}} \\
& \text { PP test: } \mathrm{y}_{\mathrm{t}}=\alpha_{0}+\alpha_{1} \mathrm{y}_{\mathrm{t}-1}+v_{\mathrm{t}}
\end{aligned}
$$

where $\mathrm{y}_{\mathrm{t}}$ is import or export in the relevant equation, $\varepsilon_{\mathrm{t}}$ and $v_{\mathrm{t}}$ represent white noise error terms, and $\Delta$ represents the first difference operator. The null hypothesis of unit root, that is non-stationarity, is that $\gamma_{1}=0$ for the ADF test and $\alpha_{1}$ 
$=1$ for the PP test. The results of the unit root tests are reported in Table 1. Research has shown that the tests of unit roots are sometimes unable to reject the null hypothesis of unit root when it is false against plausible alternatives (Dejong and Whiteman 1991) therefore these tests must be interpreted with caution.

\section{TEST FOR CO-INTEGRATION}

Engle and Granger (1987) have shown that a linear combination of two or more non-stationary series may be stationary. If such stationary unit root series, $\mathrm{I}(0)$ or combination exists, the non-stationary series, I(1) are said to be co integrated. Consider a VAR model of order $\mathrm{p}$ :

$\mathrm{y}_{\mathrm{t}}=\mathrm{A}_{1} \mathrm{y}_{\mathrm{t}-1}+\mathrm{A}_{2} \mathrm{y}_{\mathrm{t}-2}+------+\mathrm{A}_{\mathrm{p}} \mathrm{y}_{\mathrm{t}-\mathrm{p}}+\mathrm{Bx}_{\mathrm{t}}+\varepsilon_{\mathrm{t}}$

where $y_{t}$ is a $k \times 1$ vector of non-stationary I(1) series, $x_{t}$ is a vector of deterministic variables, $\varepsilon_{t}$ is a vector of innovations. If we subtract $\mathrm{y}_{\mathrm{t}-1}$ from both sides of (5), we can rewrite the VAR as:

$\Delta \mathrm{y}_{\mathrm{t}}=\Gamma \mathrm{y}_{\mathrm{t}-1}+\Sigma \Pi_{\mathrm{i}} \Delta \mathrm{y}_{\mathrm{t}-\mathrm{i}}+\mathrm{Bx}_{\mathrm{t}}+\varepsilon_{\mathrm{t}}$

where

$\Gamma=\sum_{i=1}^{\sum A_{i}-I,} \quad \Pi_{i}=-\underset{j=i+1}{\sum A_{j}}$

The Johansen's test of co integration (Johansen and Juselius 1990) is used for this test. The trace test is a test of hypothesis that there is at most $r$, (the rank of the estimated matrix $\Gamma$ ) co integrating vectors against the alternative hypothesis of full rank $r+1$. If the rank of $\Gamma=0$, then there is no co integrating relationship among the variables and the first difference specification can be used to estimate the VAR model. However, if the coefficient matrix of $\Gamma$ has a reduced rank such that the rank of $\Gamma=\mathrm{r}(\mathrm{r}<\mathrm{k})$ where $\mathrm{k}$ is the number of variables in the system, we can say that there are $\mathrm{r}$ co integrating vectors. In that case there exist $\mathrm{k} \times \mathrm{r}$ matrices $\alpha$ and $\beta$ each with rank $\mathrm{r}$ such that $\Gamma=\alpha \beta^{\prime}$ and $\beta^{\prime} \mathrm{y}_{\mathrm{t}}$ is stationary, (Johansen, 1990), (Eun and Jeong, 1999). Г $y_{\mathrm{t}-\mathrm{k}}$ is referred to as the error correction term. Johansen has developed two likelihood ratio test statistics, the trace statistic $\left(\lambda_{\text {trace }}\right)$ and maximum eigenvalue statistic $\left(\lambda_{\max }\right)$ to determine the rank $\mathrm{r}$ for the estimated matrix, $\Gamma$. The null hypothesis that export and import variables for each country in the sample are not co integrated $(r=0)$ is tested against the alternative hypothesis of one or more co integrating vectors $(r>0)$.

\section{THE VAR MODEL}

The standard method of specifying the dynamic relationship among several variables relies upon the specification of the structural model. The vector autoregression (VAR) method, being a data-induced technique places a minimal theoretical emphasis on the structural relationship, but simply involves the specification of the set of endogenous variables that are believed to have logical relationship and qualify for inclusion as part of the economic system. The procedure involves the specification of the appropriate lag length needed to capture most of the effects from the variables. Although not desired, we have specified a structural model to explain how supply constraints limit African countries' ability to export to the U.S. market. Similarly, we also constructed a structural model that explains the inability of African countries to buy significant amount of American imports.

The models show that there is a strong autocorrelation between lagged values of African imports from and exports to the U. S. market. The use of co-integration and error correction procedures in the VAR models enables us to eliminate the effect of the autocorrelation problems. It also allows us to determine how import and export variables respond over time to a shock from each of the demand and supply variables. The appropriate lag length was determined by means of the Akaike Information Criterion (AIC) and the likelihood ratio test proposed by (Sims, 1980). The specifications were estimated with 2 lags because the specifications with 2 lags yield minimum model 
standard error. Although various lag lengths were tested, the Akaike Information Criterion statistic (AIC), showed that we could not reject the null hypothesis that 2 lags were appropriate for the estimation of the export model in the case of Cote d'Ivoire, Egypt, and Nigeria and import for South Africa. The dynamic responses of the various innovations to the import and export variables have been evaluated, using Choleski variance decomposition and the impulse response coefficients proposed in (Doan, 1989). To reduce the number of Tables, the variance decomposition statistics are not provided.

The null hypothesis tested in this study is that African countries do not possess the capacity to export a significant amount of products to the US market, because they lack the capacity to produce, and because their currencies are not properly aligned with the US dollar. We also tested the hypothesis that they also lack the capacity to purchase American exports because of low per capita GDP. Exports from countries with overvalued currency will be too expensive for American consumers who will curtail their demand. Overvalued currency will hurt the domestic sectors engaged in tradable goods and services and will make imports relatively cheaper, including industrial inputs. For countries that require capital goods and raw materials imports for their industrialization, as was the case in Nigeria in the 1970's, this will be beneficial. In the context of general equilibrium and balance of trade considerations, it is however more beneficial to maintain a properly aligned exchange rate regime, especially where import and export activities are mutually dependent. Overvalued exchange rate may not always reduce the importation of critical commodities, such as energy and inputs needed for development program.

Before presenting the empirical results of this study, it is necessary to acknowledge that the results are based upon the theoretical procedures of the VAR model that have been widely discussed in the literature, such as the (Johansen, 1991) model. We will therefore make only passing references to those theoretical issues in this paper. The Johansen cointegration test is given as:

$\Delta \mathrm{y}_{\mathrm{t}}+\underset{ }{\mathrm{t}}=1 \ldots \ldots \ldots \mathrm{T} \beta_{\mathrm{i}} \Delta \mathrm{y}_{\mathrm{t}-\mathrm{i}}+\alpha \mathrm{y}_{\mathrm{t}-\mathrm{k}}+\varepsilon_{\mathrm{t}}$

where $\mathrm{y}_{\mathrm{t}-\mathrm{k}}$ are exogenous variables and $\varepsilon_{1} \ldots \ldots . \varepsilon_{\tau}$ are white noise error terms, which have zero means and variance $\sigma_{\varepsilon}$ and are serially uncorrelated. Equation (5) can be written in a matrix form as:

$\Gamma(\phi) \mathrm{Y}_{\mathrm{t}}=\Gamma+\mathrm{V}_{\mathrm{t}}$

$\Gamma(\phi)=I-\Gamma_{1} \phi-\Gamma_{2} \phi^{2}-. \Gamma_{m} \phi^{m}$

where $Y_{t}$ is an $n \times 1$ vector of variables, $\Gamma$ is an $n \times 1$ vector of constants, and $V_{t}$ is an $n \times 1$ vector of random innovations. Equation (9) is a normalized polynomial in lagged operator $\phi$. By solving the orthogonal polynomial in equation (9), we can obtain the eigenvalues representing the correlation between the linear combinations of $\Delta \mathrm{y}_{\mathrm{t}}$ and the linear combinations of $\mathrm{y}_{\mathrm{t}-\mathrm{k}}$. This procedure enables us to perform error decomposition and impulse response analyses, which can be used to determine the interaction of the various demand and supply constraints on the US imports from and exports to each of the countries in the sample.

\section{EMPIRICAL RESULTS: MARGINAL PROPENSITY TO IMPORT}

The tests results are mixed across the six countries. Using the countries' real GDP relative to the U. S. GDP, and the real per capita GDP, we report mixed results in which the marginal propensity to import is greater than unity, except in the case of Nigeria and South Africa. While higher relative GDP induces lower U. S. exports to Cote d'Ivoire, Morocco, and South Africa, higher real per capita GDP produces similar effect in the case of Egypt, Ethiopia and Nigeria. The results reveal that U. S. exports to, and imports from all the countries in the sample are mutually dependent, as revealed by the co-integrating equations. The results also show that they are determined, to some extent by their lagged values. The lagged horizon can be as long as two years, as in the case of U. S. imports from Cote d'Ivoire. Measured by their GDP, relative to the U. S. GDP, the marginal propensity to import by these countries lies 
somewhere between -2 and $+2,\left(-2<\alpha_{1}, \alpha_{2}<2\right)$.

The results show that the responsiveness of import to real exchange rate in the countries in the sample is very low, $\left(0<\alpha_{3}<1\right)$. We do not always obtain the expected negative sign for $\alpha_{3}$, as in the case of Nigeria. We do not have a plausible explanation for these situations. In a few cases, the real exchange rate is not statistically significant in the import equation, although the value and sign of the coefficients are consistent with the structural rigidity assumption in the models. The value of $\alpha_{3}$ for most of the countries is in the neighborhood of -0.33 , hence we believe that the true value may be -0.30 which is the average across the countries in the sample. Our database shows that Ethiopia, Egypt and Nigeria, to a greater extent experienced exchange rate depreciation beginning somewhere around 1990. On the contrary, Cote d'Ivoire, Morocco and South Africa experienced a measure of exchange rate appreciation during the same period. Morocco's increased demand for U. S. imports during this period is consistent with its exchange rate appreciation policy.

\section{MARGINAL PROPENSITY TO EXPORT}

The marginal propensity to export is represented by $\beta_{1}$, the coefficient of the real per capita GDP. We believe that the numerical value of this estimate is greatly affected by the countries' industrial production capability and the countries' real exchange rate policy. According to (Michael Evans, 2004), a 1\% increase in the U. S. industrial production index will stimulate about $1 / 2 \%$ increase in the U. S. export. Excluding Cote d'Ivoire and South Africa where the coefficient of (IPI) is negative, our estimate is approximately three times higher. Using their real per capita GDP, which accounts for the countries' ability to produce goods and services and the quality of the infrastructure, the results reveal that all the countries without any exception face a serious supply-side constraint. The results show that their marginal propensity to export is generally much less than unity. Except for Cote d'Ivoire where a $1 \%$ increase in the country's real per capita GDP induces about $0.44 \%$ increase in export, a similar percentage increase in real per capita GDP in Egypt, Ethiopia, Morocco, and South Africa actually causes export to fall approximately $0.75 \%$.

The responsiveness of export to real exchange rate is not clearly understood. Firstly, the sign of the coefficient is unexpectedly positive for Cote d'Ivoire and Ethiopia. Secondly, the numerical value is unusually large for Cote d'Ivoire and Morocco, being approximately equal to unity or greater. This means that for these two countries, a one-percentage increase in real exchange rate may bring about an identical increase or decrease in export. Where the responsiveness of export to real exchange rate appreciation is less than unity as expected, the coefficients are statistically insignificant. Our database shows that most of the countries were operating a "managed" exchange rate regime, (Evans, 2004), (IMF, 2003). We observed that between 1970 and 1993, Ethiopian exchange rate was virtually unchanged. Other countries also "managed" their exchange rate at different periods. Another factor which seems to blur the real effect of exchange rate is the role of speculators (DeLong, 2002). As a result of these phenomena U. S. exports to Cote d'Ivoire and Morocco remained fairly stable until 1994. On the contrary the, U. S. exports to Nigeria soared to a new height.

\section{CONCLUSIONS}

This study presents the results of an empirical analysis of the U. S. exports to, and imports from six African countries. Although we conclude that the countries in the sample have a high marginal propensity to import, generally grater than unity, and a very low marginal propensity to export, we can never claim to understand why there has been so little trade between the United States and African countries. We observe statistically significant increase and decrease in the demand for U. S. imports in a few countries, in spite of very low real per capita GDP. We also observe a small but statistically significant increase or decrease in exports in some countries with identically low real per capita GDP. For these reasons, we must avoid making a general conclusion, even for countries with identical economic conditions. African economies are too atypical and heterogeneous in nature, with different domestic needs and aspirations. While exports may be determined by the level and type of technology which dictates their inability to produce, imports may not be determined by pure marginal propensity to consume, but by a whole complex situations, including cultural orientation. Pure marginal propensity to consume is determined by the desired basket of consumer goods, inputs for domestic industrial and infrastructural improvements and other things like that. The demand for such 
goods may easily conform to economic theory in a way other complex considerations do not. In such situations, imports may either be limited or easily be allowed to exceed exports without regard to real exchange rate or real per capita GDP.

Because of the heterogeneous nature of the African economies in which the demand for imports depends less on pure economic factors and more on local cultural and other circumstances, the results of this study does not lend itself to general application across many countries. The shortcoming of this study lies perhaps in the choice of constraints instruments. This author believes that the use of GDP as a constraints-instrument is perhaps too aggregative and hence incapable of identifying specific constraints, which may be at the core of the problem. More suitable constraint-instruments may include non-quantifiable policy instruments, such as tax policies, and regulations. Others include poor technology and social infrastructures such as roads and communications systems.

Lastly, there is a mutual lagged dependency in the U. S. trade with African countries. An example of this is between exports and imports in Cote d'Ivoire, Egypt, Nigeria and South Africa. The lagged dependency extends up to two years in a number of cases, such as Cote d'Ivoire and Nigeria. For these countries, and others in similar circumstances, their ability to import from the United States heavily depends on their ability to export to the U. S. market.

\section{ACKNOWLEDGEMENT}

I acknowledge the various contributions of my Graduate Students and in particular El-Tonya V. Duckworth for data collection and processing.

Table 1a: Unit Root Test

Augment Dickey-Fuller Test

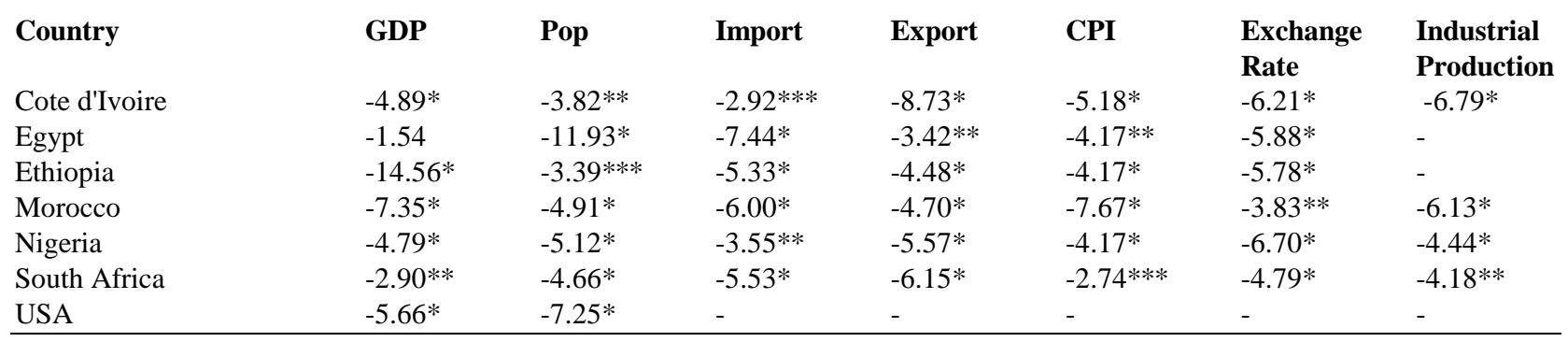

Table 1b: Unit Root Test

\begin{tabular}{|c|c|c|c|c|c|c|c|}
\hline \multicolumn{8}{|c|}{ Phillips-Perron } \\
\hline Country & GDP & Pop & Import & Export & CPI & $\begin{array}{l}\text { Exchange } \\
\text { Rate }\end{array}$ & $\begin{array}{l}\text { Industrial } \\
\text { Production }\end{array}$ \\
\hline Cote d'Ivoire & $-4.89 *$ & $-3.90 * *$ & $-7.47 *$ & $-12.50 *$ & -6.82 & $-6.26^{*}$ & $-8.98 *$ \\
\hline Egypt & $-8.46^{*}$ & $-16.73 *$ & $-7.44 *$ & $-3.48 * *$ & $-7.73 *$ & $-5.88 *$ & - \\
\hline Ethiopia & $-14.25^{*}$ & $-3.39 * *$ & $-5.33^{*}$ & $-4.37 *$ & $-4.21 * *$ & $-5.79 *$ & - \\
\hline Morocco & $-7.35^{*}$ & $-4.92 *$ & $-6.00^{*}$ & $-11.74 *$ & -8.03 & $-3.91 * *$ & $-6.13^{*}$ \\
\hline Nigeria & $-4.81 *$ & $-5.12 *$ & $-3.33 * * *$ & $-5.68 *$ & -1.54 & $-5.23 *$ & $-5.50 *$ \\
\hline South Africa & $-2.90 * *$ & $-4.64 *$ & $-13.51^{*}$ & $-8.03 *$ & $-3.90^{*}$ & $-4.79 *$ & $-4.11 * *$ \\
\hline USA & $-5.68 *$ & $-7.27 *$ & - & - & - & - & - \\
\hline
\end{tabular}


Table 2: Co-Integration Rank Test

\begin{tabular}{|c|c|c|c|c|c|c|}
\hline \multicolumn{7}{|c|}{ Trace Test (Import Model) } \\
\hline & Cote d'Ivoire & Egypt & Ethiopia & Morocco & Nigeria & South Africa \\
\hline r: None & 83.56* & $37.00 *$ & $67.03 *$ & 14.69 & $32.05 *$ & 19.40 \\
\hline $\mathrm{r}:>1$ & 1.36 & $13.60^{* *}$ & $12.21 * *$ & 0.003 & $6.07 * *$ & 1.85 \\
\hline \multicolumn{7}{|c|}{ Trace Test (Export Model) } \\
\hline r: None & $93.79 *$ & $22.45^{* *}$ & $34.93 *$ & 11.55 & $22.43 *$ & 13.32 \\
\hline $\mathrm{r}:>1$ & 3.84 & 3.71 & 7.54 & 0.10 & 2.06 & 1.33 \\
\hline \multicolumn{7}{|c|}{ Maximum-Eigenvalue Test (Import Model) } \\
\hline r: None & $82.22 *$ & $23.40^{* *}$ & $54.82 *$ & $14.69 *$ & $25.98 *$ & 17.55 \\
\hline $\mathrm{r}:>1$ & 1.36 & $13.60^{* *}$ & 12.21 & 0.003 & 6.07 & 1.85 \\
\hline \multicolumn{7}{|c|}{ Maximum-Eigenvalue Test (Export Model) } \\
\hline r: None & $89.94 *$ & $18.74 *$ & $27.40 *$ & 11.45 & $20.37 *$ & 11.99 \\
\hline $\mathrm{r}:>1$ & 3.84 & 3.71 & 7.54 & 0.10 & 2.06 & 1.33 \\
\hline
\end{tabular}

Table 3a: The VAR Import Model

\begin{tabular}{|c|c|c|c|c|c|c|}
\hline Ind. Variables & Cote d'Ivoire & Egypt & Ethiopia & Morocco & Nigeria & South Africa \\
\hline \multicolumn{7}{|c|}{ Cointegrating Eq. } \\
\hline $\log (\mathrm{im} / \mathrm{y})(-1)$ & 1.00 & 1.00 & 1.00 & 1.00 & 1.00 & 1.00 \\
\hline \multirow[t]{2}{*}{$\log (e x / y)(-1)$} & 0.34 & -3.68 & 0.90 & -3.71 & -0 & 0.77 \\
\hline & $(3.36)^{*}$ & $(5.27)^{*}$ & $(8.84)^{*}$ & $(7.69)^{*}$ & $(1.51)$ & $(2.59)^{* *}$ \\
\hline Constant & 3.34 & -5.66 & 5.28 & -8.45 & -2.83 & 0.79 \\
\hline \multicolumn{7}{|l|}{ Error Correction } \\
\hline CointEq1 & $\begin{array}{c}-0.88 \\
(9.89)^{*}\end{array}$ & $\begin{array}{c}0.05 \\
(0.21)\end{array}$ & $\begin{array}{c}-0.61 \\
(10.76) *\end{array}$ & $\begin{array}{c}-0.30 \\
(2.73)^{* *}\end{array}$ & $\begin{array}{c}-0.66 \\
(2.13)^{* *}\end{array}$ & $\begin{array}{c}-0.51 \\
(2.84)^{* *}\end{array}$ \\
\hline \multirow[t]{2}{*}{$\operatorname{Dlog}(\mathrm{im} / \mathrm{y})(-1)$} & -0.03 & -0.57 & -0.12 & -0.07 & 0.23 & 0.18 \\
\hline & $(0.19)$ & $(1.71)$ & $(0.82)$ & $(0.42)$ & $(0.88)$ & $(0.91)$ \\
\hline \multirow[t]{2}{*}{$\operatorname{Dlog}(\mathrm{im} / \mathrm{y})(-2)$} & -0.19 & -0.71 & 0.21 & -0.10 & -0.17 & 0.36 \\
\hline & $(1.13)$ & $(2.79)^{* *}$ & $(1.38)$ & $(0.63)$ & $(0.69)$ & $(1.81)$ \\
\hline \multirow[t]{2}{*}{$\operatorname{Dlog}(e x / y)(-1)$} & 0.25 & 0.65 & 0.32 & -0.85 & -0.13 & -0.34 \\
\hline & $(1.13)$ & $(0.94)$ & $(1.84) * * *$ & $(2.67)^{* * *}$ & $(0.57)$ & $(1.27)$ \\
\hline $\operatorname{Dlog}(e x / y)(-2)$ & -0.06 & $\begin{array}{l}-0.62 \\
-0.011\end{array}$ & $\begin{array}{l}-0.13 \\
-076\end{array}$ & $\begin{array}{l}-0.17 \\
-0.79)\end{array}$ & $\begin{array}{l}-0.35 \\
-0.53)\end{array}$ & -0.27 \\
\hline \multirow[t]{2}{*}{ Constant } & -2.68 & 4.88 & 14.78 & -6.01 & 0.82 & -0.61 \\
\hline & $(1.87)$ & $(1.07)$ & $(6.91)^{*}$ & $(1.58)$ & $(0.57)$ & $(0.26)$ \\
\hline \multirow[t]{2}{*}{$\log (y / y u s)$} & -1.63 & 0.27 & 2.15 & -1.99 & 0.19 & -0.41 \\
\hline & $(7.06)^{*}$ & $(0.22)$ & $(5.85)^{*}$ & $(2.52)^{* *}$ & $(0.77)$ & $(2.35)^{* * *}$ \\
\hline \multirow[t]{2}{*}{$\log (($ y/pop $) / c p i)$} & 2.48 & -1.63 & -2.18 & 1.63 & -0.20 & 0.70 \\
\hline & $(9.42)^{*}$ & $(1.81)^{* * *}$ & $(10.50)^{*}$ & $(2.82) * *$ & $(0.28)$ & $(1.30)$ \\
\hline \multirow[t]{2}{*}{$\log (\mathrm{er} / \mathrm{cpi})$} & -0.43 & -0.06 & -0.35 & -0.46 & 0.12 & -0.31 \\
\hline & (1.30) & $(0.22)$ & (1.26) & (1.23) & (1.67) & (1.33) \\
\hline $\mathrm{R}^{2}$ Adj. & 0.827 & 0.241 & 0.854 & 0.540 & 0.312 & 0.134 \\
\hline SS Resid. & 0.80 & 3.55 & 0.68 & 0.29 & 1.09 & 0.38 \\
\hline Log likelihood & 12.61 & -10.39 & 15.24 & 28.14 & 7.92 & 24.07 \\
\hline Akaike AIC & -0.23 & 1.25 & -0.40 & -1.23 & 0.07 & -0.97 \\
\hline
\end{tabular}


Table 3b: The VAR Export Model

\begin{tabular}{|c|c|c|c|c|c|c|}
\hline Ind. Variables & Cote d'Ivoire & Egypt & Ethiopia & Morocco & Nigeria & South Africa \\
\hline \multicolumn{7}{|c|}{ Cointegrating Eq. } \\
\hline $\log (e x / y)(-1)$ & 1.00 & 1.00 & 1.00 & 1.00 & 1.00 & 1.00 \\
\hline \multirow{2}{*}{$\log (\mathrm{im} / \mathrm{y})(-1)$} & 1.78 & -0.38 & -0.11 & -0.27 & -1.10 & -8.01 \\
\hline & $(9.94)^{*}$ & $(2.20)$ & $(1.15)$ & $(3.89)^{*}$ & $(3.40)^{*}$ & $(3.37)^{*}$ \\
\hline Constant & 7.33 & 1.00 & 2.36 & 2.26 & 2.47 & -29.63 \\
\hline \multicolumn{7}{|c|}{ Error Correction } \\
\hline \multirow[t]{2}{*}{ CointEq1 } & -0.35 & -0.19 & -0.92 & -0.81 & -0.48 & 0.01 \\
\hline & $(10.26)^{*}$ & $(1.91)$ & $(3.84)^{*}$ & $(2.58)^{* *}$ & $(4.22)^{*}$ & $(2.11)^{* *}$ \\
\hline \multirow[t]{2}{*}{$D \log (e x / y)(-1)$} & -0.36 & -0.13 & 0.19 & -0.33 & 0.26 & -0.55 \\
\hline & $(2.34)^{* *}$ & $(0.77)$ & $(1.16)$ & $(1.29)$ & $(1.78)^{* * *}$ & $(2.91)^{* *}$ \\
\hline \multirow[t]{2}{*}{$\operatorname{Dlog}(e x / y)(-2)$} & -0.29 & -0.43 & -0.13 & -0.31 & -0.15 & -0.42 \\
\hline & $(1.88)^{* * *}$ & $(2.47)^{* *}$ & $(0.86)$ & (1.57) & $(0.98)$ & $(2.32)^{* *}$ \\
\hline \multirow[t]{2}{*}{$\operatorname{Dlog}(\mathrm{im} / \mathrm{y})(-1)$} & 0.39 & 0.07 & 0.03 & -0.20 & -0.35 & -0.19 \\
\hline & $(2.95)^{* *}$ & $(1.05)$ & $(0.54)$ & $(1.07)$ & $(2.49)^{* *}$ & $(1.32)$ \\
\hline \multirow[t]{2}{*}{$\operatorname{Dlog}(\mathrm{im} / \mathrm{y})(-2)$} & 0.26 & 0.04 & 0.08 & -.004 & -0.29 & 0.07 \\
\hline & $(1.93)^{* * *}$ & $(0.74)$ & $(1.54)$ & $(0.02)$ & $(2.16)^{* *}$ & $(0.51)$ \\
\hline \multirow[t]{2}{*}{ Constant } & 0.74 & 1.99 & 5.79 & 11.08 & -1.65 & 4.98 \\
\hline & $(0.54)$ & $(2.36)^{* *}$ & $(3.74)^{*}$ & $(3.02)^{*}$ & $(2.09)^{* *}$ & $(2.60)^{* *}$ \\
\hline \multirow[t]{2}{*}{$\log (y / p o p)$} & 0.44 & -0.61 & -0.79 & -0.78 & 0.22 & -0.86 \\
\hline & $(2.05)^{* *}$ & $(2.56)^{*}$ & $(3.74)^{*}$ & $(2.03)^{* *}$ & $(0.73)$ & $(1.57)$ \\
\hline \multirow[t]{2}{*}{$\log (\mathrm{IPI})$} & -1.28 & - & - & 0.09 & 0.30 & -0.20 \\
\hline & $(10.42)^{*}$ & - & - & $(0.15)$ & $(2.49)^{* *}$ & $(0.51)$ \\
\hline \multirow[t]{2}{*}{$\log ($ er/cpi) } & 0.89 & -0.04 & 0.16 & -1.40 & -0.08 & -0.02 \\
\hline & $(3.65)^{*}$ & $(0.68)$ & $(2.50)^{* *}$ & $(2.57)^{* *}$ & $(1.72)^{* * *}$ & $(0.11)$ \\
\hline R2 Adj. & 0.88 & 0.48 & 0.59 & 0.57 & 0.47 & 0.31 \\
\hline SS Resid. & 0.51 & 0.56 & 0.19 & 0.38 & 0.45 & 0.23 \\
\hline Log Likelihood & 19.47 & 31.36 & 35.09 & 24.19 & 21.42 & 32.22 \\
\hline Akaike AIC & -0.67 & -1.51 & -1.75 & -0.98 & -0.80 & -1.50 \\
\hline
\end{tabular}

* Statistically Significant at 1\%. ** Statistically Significant at 5\%. *** Statistically Significant at $10 \%$

\section{REFERENCES}

1. Amuedo-Dorantes \& Susan Pozo (1997). Exchange Rate Volatility and Economic Growth (unpublished). A paper presented at the Midwest Economics Association Annual Meeting, Kansas City, MO, March 20-22.

2 Almansi, Aquiles A. (1989). Patterns in External Adjustment in LDCs: Do We Understand Them? International Economic Review, volume 30(1).

3. Chhibber, Jay \& Nemat Shafik (1992). Devaluation and Inflation with Parallel Markets: an Application to Ghana Journal of African Finance and Economic Development, volume 1 No. 1 (Spring).

4. DeLong, J. Bradford, 2002). Macroeconomics, McGraw-Hill.

5. Dejong, D. N. \& C. H. Whiteman (1994), Trends and Random Walks in Macroeconomic Time Series: A Reconsideration Based on the Likelihood Principle, Journal of Monetary Economics.

6. Doan, T. (1989), Rats User's Manual, Version 3.02 (Evanston, Il; Var Econometrics, Illinois.

7. Engle R. E. \& C. W. J. Granger (1987): Cointegration and Error-Correction: Representation, Estimation, and Testing Econometrica, 55, Pages 251-276.

8. Esfahani, Hadi Salehi (1991), Exports, Imports and Economic Growth in Semi Industrialized Countries, Journal of Economic Development, volume 35, 93-116. 
9. $\quad$ Evans, Michael K. (2004) Macroeconomics for Managers, Blackwell Publishing.

10. Faini, Ricardo \& Jaime de Melo (1990). LDC adjustment package Economic Policy.

11. Feder, Gershon (1982). On Exports and Economic Growth, Journal of Development Economics, volume 12, 59-73.

12. Gyimah-Brempong, K. (1991). Export Instability and Economic Growth in Sub Saharan Africa, Economic Development and Cultural Change, volume 39, No. 4.

13. International Monetary Fund (IMF). International Financial Statistics, various years.

14. Johansen, Soren and Katerina Juselius (1990). Maximum Likelihood Estimation and Inferences on Cointegration with Application to the Demand for Money, Oxford Bulletin of Economics and Statistics 52 , Pages 169-209.

15. Ntoko, A. Ngome (1992). Structural adjustment in Africa: A Note on Adjustment Patterns, and Economic Structure, (Unpublished paper presented at the Eastern Economic Association Meeting in Washington DC).

16. Osterwald-Lenum, Michael (1992). A note with Quantiles of the Assumptotic distribution of the Maximum Likelihood Co-integration Rank Test Statistics, Oxford Bulletin of Economics and Statistics, vol 54, No. 3.

17. UNCTAD (1991). Trade and Development Report.

18. Rana, Pradumana B. (1988). Export, Policy Changes and Economic Growth in Developing Countries after the 1973 Oil Shock, Journal of Development Economics, volume 28, 261-264.

19. Tyler, G. (1981), Growth and Export Expansion in Developing Countries: Some Empirical Evidence, Journal of Development Economics, volume 9, No. 1.

20. U.S. Department of Commerce, International Trade Administration, US Foreign Trade Highlights, (various years).

\section{NOTES}

